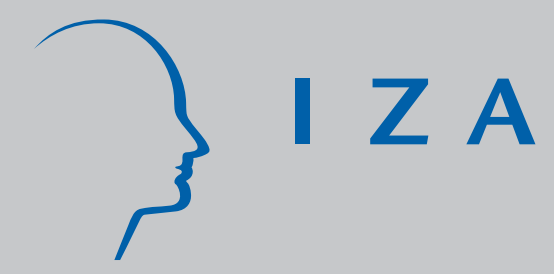

IZADP No. 2102

Market Power, Dismissal Threat and Rent Sharing: The Role of Insider and Outsider Forces in Wage Bargaining

Anabela Carneiro

Pedro Portugal

April 2006 


\title{
Market Power, Dismissal Threat and Rent Sharing: The Role of Insider and Outsider Forces in Wage Bargaining
}

\author{
Anabela Carneiro \\ Universidade do Porto and CETE \\ Pedro Portugal \\ Banco de Portugal, Universidade Nova de Lisboa \\ and IZA Bonn
}
Discussion Paper No. 2102
April 2006

IZA

P.O. Box 7240

53072 Bonn

Germany

\author{
Phone: +49-228-3894-0 \\ Fax: +49-228-3894-180 \\ Email: iza@iza.org
}

\begin{abstract}
Any opinions expressed here are those of the author(s) and not those of the institute. Research disseminated by IZA may include views on policy, but the institute itself takes no institutional policy positions.

The Institute for the Study of Labor (IZA) in Bonn is a local and virtual international research center and a place of communication between science, politics and business. IZA is an independent nonprofit company supported by Deutsche Post World Net. The center is associated with the University of Bonn and offers a stimulating research environment through its research networks, research support, and visitors and doctoral programs. IZA engages in (i) original and internationally competitive research in all fields of labor economics, (ii) development of policy concepts, and (iii) dissemination of research results and concepts to the interested public.
\end{abstract}

IZA Discussion Papers often represent preliminary work and are circulated to encourage discussion. Citation of such a paper should account for its provisional character. A revised version may be available directly from the author. 
IZA Discussion Paper No. 2102

April 2006

\begin{abstract}

\section{Market Power, Dismissal Threat and Rent Sharing: The Role of Insider and Outsider Forces in Wage Bargaining}

One of the predictions of the insider-outsider theory is that wages will be higher in sectors (firms) with high labor adjustment costs/high turnover costs. This prediction is tested empirically in this study, using an insider-outsider model and a longitudinal panel of large firms in Portugal. The results revealed that firms where insider workers appear to have more market power tend to pay higher wages. In particular, we found that the threat of dismissal acts to weaken insiders' bargaining power and, consequently, to restrain their wage claims. Moreover, the results also showed that real wages in Portugal are downward rigid.
\end{abstract}

JEL Classification: J30, J31

Keywords: $\quad$ wages, market power, dismissal threat, rent sharing, system GMM estimator

Corresponding author:

Anabela Carneiro

Faculdade de Economia da Universidade do Porto

Rua Dr. Roberto Frias

4200-464 Porto

Portugal

Email: anacar@fep.up.pt

\footnotetext{
* We gratefully acknowledge the Departamento de Estatística do Ministério da Segurança Social e do Trabalho for allowing us to use the data from the Social Audit. We also thank Manuel Arellano for kindly supplying us with the DPD program. Financial support from Fundação para a Ciência e Tecnologia (FCT) under research grant POCTI/ECO/35147/99 is also warmly acknowledged.
} 


\section{Introduction}

It is widely agreed that labor turnover costs (LTC) give insider workers market power which they can exploit to their own advantage. In fact, insiders' positions are protected by LTC which give them some labor market power in the process of wage negotiation. The insider-outsider approach relies on the assumption that wages are set through bargaining, not between firms and the whole labor force, but rather between firms and their workers. In this context wages might be widely influenced by firm's internal conditions rather than by external conditions and it should be expected that the greater the hiring and firing costs, the more the insider wage will depend on the "inside factors" relative to the "outside factors". Furthermore, it should also be expected that in countries/sectors wih high job security and/or high adjustment costs the threat of dismissal is relatively stronger because mean unemployment duration tends to be longer (Blanchard and Portugal, 2001).

In fact, relying on the distinction between insider and outsider workers, the insider-outsider theory of wage formation aimed to explain why wages may be set above their market-clearing levels. ${ }^{1}$ The insider-outsider explanation is based on the idea that the level of wages is primarily determined by the currently employed workers (the so-called 'insiders'), with unemployed (the 'outsiders') playing little or no role in the process of wage bargaining. Furthermore, this approach attempts to explain why unemployed workers do not compete for existing jobs by offering to work at jobs for which they are qualified at a wage lower than that currently being paid to incumbents. Lindbeck and Snower (1986) showed that the existence of costs associated with insider-outsider turnover might explain why firms do not replace their high-wage insiders with low-wage outsiders. Accordingly, involuntary unemployment can arise due to the existence of LTC such as hiring, training and firing costs or the costs generated by the disincentive to cooperate with outsiders, that make it costly to the firm to replace an insider worker with an unemployed worker. ${ }^{2}$ The rents associated with these labor market frictions give some labor market power to insiders in the process of wage setting.

Based on this theoretical framework the microeconometric models of wage determination started including measures of the firm's profits or financial performance as explanatory variables. This literature has focussed directly on rentsharing models [see, among others, Nickell and Wadhwani (1990), Holmlund and Zetterberg (1991), Abowd and Lemieux (1993), Blanchflower et al. (1996) and Hildreth and Oswald (1997)]. These studies used panel data at both firm or industry level and estimated versions of the wage equation with rents per worker included. Albeit using different models of collective bargaining, the results of these studies indicate, in general, that changes in profitability are shown to feed through into long-run changes in wages. A branch of this literature, to which this paper is more closely related, has been focussing on the relative importance of insider versus outsider forces in wage determination [see, for instance, Nick-

\footnotetext{
${ }^{1}$ See, for example, Lindbeck and Snower (1985, 1986 and 1988) and Solow (1985).

${ }^{2}$ For a description of this type of costs see Lindbeck and Snower (1986).
} 
ell and Wadhwani (1990), Holmlund and Zetterberg (1991) and Bentolila and Dolado (1994)]. These studies show that firm specific factors, as well as general labor market conditions, have an important role on the process of wage determination, although the weight attached to firm-specific factors varies considerably across countries. Indeed, the results suggest that firm-specific factors are relatively unimportant in the Nordic Countries, of significant importance in Britain, West Germany, Spain and the Netherlands, and highly important in Australia, Canada and the United States. ${ }^{3}$ Probably based in the studies of Blanchard and Summers (1986) and Gottfries and Horn (1987), these empirical studies have also been concerned with the existence of hysteresis effects (i. e., dependence of current unemployment on past unemployment) arising from insider power. In particular, they test to what extent current wages depend inversely on past employment. Concerning this issue, the empirical evidence remais rather mixed and unsettled. Some of these studies also present evidence consistent with the idea that wage adjustments are asymmetric, in the sense firms' wages may be more responsive to insider variables in good than in bad times.

Using an approach inspired in the one first developed by Nickell and Wadhwani (1990), this study examines to what extent the existence of a high adjustment costs has some influence in the process of wage negotiation. In particular, we analyse if the risk of being laid off has any impact on insiders' bargaining power and, consequently, on their wages claims. For this purpose, we use data from 820 large Portuguese firms from all sectors over the period 1993-99. At this respect, we believe that Portugal is a well suited case to better identify the impact of a dismissal threat on wages, since Portugal may be classified as an extreme case of employment protection [see OECD (1999) rankings]. Portuguese stricter legislation is associated with lower turnover (high adjustment costs) in the labor market, with both jobs and unemployment spells tending to last longer. As pointed out by Blanchard and Portugal (2001), even though the unemployment rate in Portugal over the past 15 years is quite similar to the U.S. rate, the average unemployment duration in Portugal is more than three times that of the U.S. Symmetrically, flows of workers into unemployment are three times lower in Portugal. Thus, the existence of a high unemployment duration and low arrival rates of job offers results in a high penalty of being unemployed in Portugal.

Moreover, a labor market characterized by a high employment protection with high adjustment costs and lower turnover, tends to create market power for currently employed workers that they can exploit to their own advantage. Of course, it can be argued that if turnover costs give bargaining power to workers, and thus the possibility to extract some rents, firms may try to extract those rents from the insiders. However, firms are generally unable to pass these costs on fully to their insiders because firms do not incur these costs until they replace their insiders with new entrants. Moreover, even if firms could extract some of these rents by imposing lump sum payments to insiders upon voluntary quitting

\footnotetext{
${ }^{3}$ For a summary of the insider weight estimates obtained in these studies see Table A of Appendix A.
} 
or firing "without cause", such fees are usually illegal and incentive-incompatible (Lindbeck and Snower, 2002).

In sum, the Portuguese case constitutes an extreme example of the existence of a very rigid employment protection legislation and a sclerotic labor market, which seems to provide an appropriate context to identify the impact of the risk of being laid off on the process of wage negotiation.

Two additional objectives also drive the investigation.One, is to evaluate the role and weight of insider forces in wage determination. The Portuguese industrial relations system presents some contrasting features. Whereas, on one hand, the role of massive wage-setting mechanisms and the existence of extension mechanisms point to a centralized bargaining system. On the other hand, the scattered nature of union organization, the possibility opened to employers to bargain at the firm level, and the presence of a significant wage cusshion, ${ }^{4}$ highlight aspects of decentralization that may grant employers some room of maneuver to set wages. In fact, whatever the wage floor agreed upon for each category of workers at the collective bargaining table, firms are free to pay higher wages, and they often deviate from that benchmark, adjusting to firm-specific conditions [Cardoso and Portugal (2005)].

The second is to test the existence of asymmetric effects in wage adjustments, i. e., to test the extent to which wages in Portugal are more responsive to insider variables in the face of rising demand than in the face of declining demand.

This paper will be organized as follows. The empirical framework is presented in Section 2. The data and estimation method are described in Section 3. The empirical results are summarized in Section 4. Section 5 concludes.

\section{The Empirical Model}

The model used here as a basis for the estimations follows closely those developed in Layard et al. (1991) and Nickell et al. (1994) including the extension proposed by Bentolila and Dolado (1994) that consider a firm which employs two types of workers: permanent and temporary. In these types of models it is presumed that wages are determined through negotiations between the firm and the union. In Portugal negotiations between unions and firms, at the industry level, play an important part in the determination of wages. Hence, modeling the process of wage formation at the firm level using a bargaining approach seems to be an appropriate choice for the Portuguese case.

The dynamic wage equation (1) that constitutes the basis of the empirical analysis can be written as: ${ }^{5,6}$

\footnotetext{
${ }^{4}$ The wage drift measures the difference between the current wage and the wage agreed at the collective bargaining.

${ }^{5}$ To derive equation (1), see Appendix A of Bentolila and Dolado (1994).

${ }^{6}$ The benefit replacement ratio is omitted from equation (1) since the figures for this aggregate variable are virtually constant over the period of analysis and it does not seem reasonable to include it as an explanatory variable.
} 


$$
\begin{aligned}
w_{i t}-\bar{w}_{j t}= & a_{0 i}+a_{1}\left(w_{i t-1}-\bar{w}_{j t}\right)+\left(1-a_{1}\right)\left\{\lambda \left[\left(p_{i t}+y_{i t}-n_{i t}-\bar{w}_{j t}\right)+\right.\right. \\
& \left.+(1-(\alpha+\gamma)) \Delta n_{p i t}\right]+(1-\lambda) a_{2} u_{j t}+a_{3} M S_{i t}+a_{4} \beta_{i t}+ \\
& \left.+a_{5} \phi_{i t}\right\}+\varepsilon_{i t}
\end{aligned}
$$

where $w_{i t}$ is the log real wage in firm $i, \bar{w}_{j t}$ is the outside log of the real wage in region $j$ ( $i=$ firm, $j=$ region, $t=$ time), $a_{0 i}$ is a firm fixed effect, $p_{i t}$ is the firm's output price (in logs), $y_{i t}$ is the firm's output (in logs), $n_{i t}$ is the number of employees (in logs), with $\left(p_{i t}+y_{i t}-n_{i t}\right)$ being the firm's revenue per employee (in logs) and $\Delta n_{\text {pit }}$ measures the change in permanent employment. $u_{j t}$ is the regional unemployment rate, $M S_{i t}$ is market share, $\beta_{i t}$ measures workers' relative bargaining power, $\phi_{i t}$ is the proportion of temporary workers, and $\varepsilon_{i t}$ is a well-behavied error term. ${ }^{7}$ We assume, as in Bentolila and Dolado (1994), that workers' bargaining power, $\beta$, is a function of a set of variables that are related with the firm's financial situation $(f)$ and the proportion of temporary workers $(\phi)$, i. e,

$$
\beta_{i t}=a_{4} f_{i t}+\delta \phi_{i t}
$$

The interpretation of equation (1) is straightforward. Firm's average wage per employee depends on previous wages, on firm-specific factors such as firm revenue per employee, the change in the number of insiders, the market share and workers' bargaining power and on outside factors such as the unemployment rate. The parameter $\lambda$ may be termed the 'insider weight', i. e., the long-run elasticity of firm wages relative to firm revenue per employee.

\section{Data and Estimation Method}

\subsection{The Data}

Our basic data source is the Social Audit ("Balanço Social") and includes a panel of Portuguese firms having at least 100 employees from all sectors, over the period 1993-99.

The Social Audit (SA) is gathered annually by the Portuguese Ministry of Employment. When it was first introduced (1986) it covered state-owned firms only. Since then its coverage has been spreading, first to firms with at least 500 employees, and since 1992 to firms with at least 100 employees. Responding to this survey is mandatory. On average, 2,040 firms responded to the survey each year, corresponding to a total of 772,000 workers. In fact, the $S A$ is characterized by a very high degree of coverage of large firms in Portugal.

\footnotetext{
${ }^{7}$ In order to ensure that the long-run homogeneity assumption in both the inside and outside factors is verified $[\lambda+(1-\lambda)=1]$, all nominal variables such as $w_{i t}, w_{i t-1}$ and $\left(p_{j t}+y_{i t}-n_{i t}\right)$ are measured as deviations from outside wage $\left(\bar{w}_{j t}\right)$.

${ }^{8}$ Thus, it turns out that when $\beta$ is replaced by expression (2) the temporary workers ratio coefficient, $a_{5}$, already includes the impact of the bargaining effect $(\delta)$ on wages.
} 
Each year, a respondent firm reports data on a large variety of topics concerning the workforce composition and labor costs. This is organized in six major areas: (i) firm's characteristics; (ii) employment; (iii) labor costs; (iv) occupational safety; (v) vocational training; and (vi) fringe benefits.

The collection of firm's characteristics includes information about location, economic activity (SIC codes), legal setting, employment, number of establishments and production (value-added). The existence of a unique identification number for each firm allows us to create a longitudinal panel of firms.

The employment block, which is the largest in this survey, collects detailed information about workers' attributes. This includes information about gender, age, skills, schooling, tenure, hours of work, etc. Total employment is also decomposed by type of contract and skill level, which allows one to compute the number of permanent and temporary workers at the end-of-year count.

The information about labor costs includes annual base-wage, regular paid benefits and bonus, irregular benefits and bonus, costs with vocational training, and other fringe benefits.

One of the main advantages of this data set, besides its coverage and longitudinal nature, is the availability of information on both firm's and workers' characteristiscs. The possibility of controlling the skill composition of the workforce over the years as well as the possibility of computing workers' flows constitutes an important advantage of this data set. The information about employment by type of contract is equally important.

In order to complement the information available in the $S A$ survey, we will also use the data contained on Quadros de Pessoal survey $(Q P)$. $Q P$ is an annual mandatory employment survey collected by the Portuguese Ministry of Employment that covers near all establishments with wage earners. ${ }^{9}$ In each year every establishment with wage earners is legally obliged to fill in a standardized questionnaire. Reported data cover the establishment itself (location, economic activity and employment), the firm (location, economic activity, employment, sales and legal framework) and each of its workers (gender, age, education, skill, occupation, tenure, earnings and duration of work). Currently, the data set collects information on around 250000 firms and 2.5 million employees.

The information from $Q P$ about wages will be used in order to compute the outside wage. There are two main reasons to believe that $Q P$ can provide a reliable measure of the outside wage. The first is its coverage and reliability. By law, the questionnaire is made available to every worker in a public space of the establishment. This requirement facilitates the work of the services of the Ministry of Employment that monitor compliance of firms with the law (e. g., illegal work). Indeed, the administrative nature of the data and its public availability imply a high degree of coverage and reliability. The second is that the information on earnings is very complete. It includes the base wages (gross pay for normal hours of work), seniority payments, regular benefits, irregular benefits and overtime pay.

${ }^{9}$ Public administration and household servants are excluded. 
The outside wage per employee will be defined by region (NUTs III), ${ }^{10}$ excluding the firm's own wage.

Since the data on value-added are not available in the Social Audit, the information on sales from $Q P$ will be used instead. This is possible because the identification code of firms in the $S A$ and the $Q P$ data sets is the same.

The sales variable will be used to compute a measure of productivity and a measure of market share. Thus, nominal productivity will be defined as annual sales per employee. ${ }^{11}$ The market share is obtained by the ratio between firm's sales and total (5 digit) sector's sales. ${ }^{12}$

Neither the $S A$ nor the $Q P$ datasets have information on union density. In fact, there are no micro-data in Portugal with information on the number of workers who are members of a trade union. On the other side, even though the $S A$ survey includes information about profits and financial costs, union data are not available. In order to overcome these difficulties, some proxies were used to measure workers' bargaining power. In fact, one of the main objectives of this study is to examine the extent to which insider power has an important role in wage determination using measures of workers' bargaining power somewhat different from the conventional ones such as union density and union mark-up. As pointed out by Lindbeck and Snower (2002), “...the insider-outsider theory is not just about labor unions. Any employee whose position is protected by labor turnover costs is an insider of sorts, regardless of whether he belongs to a union". As shown before, since Portugal is characterized by a stricter employment legislation with higher firing costs and low flows in and out of unemployment, it appears that there is some scope for the existence of insider power beyond the one that might result from the behavior of unions.

Hence, we include the labor utilization rate within the firm and the layoff rate as measures of insiders' bargaining power. These two variables may be viewed by insider workers as a signal of the firm's risk of illiquidity.

As initially suggested by Gregory (1986), it is probably the labor utilization rate within the firm that is particularly important for wage negotiations, rather than the labor utilization rate within the economy. The labor utilization rate may affect wages in two ways. First, higher labor utilization rates within the firm increases the probability of job retention of an insider worker raising their power of negotiation. Second, as the labor utilization rate increases, the threat of a strike becomes more credible to the firm, raising the workers' bargaining power.

The labor utilization rate (lur) is defined as the ratio between the total number of hours actually worked in the year and the maximum annual potential of hours worked (in logs). In order to minimize the endogenity problems the variable is lagged by one year. Higher labor utilization rates within the firm will induce workers to demand higher wages, ceteris paribus. The layoff rate (layof $f$ )

\footnotetext{
${ }^{10}$ At NUTs III mainland Portugal is split into 28 geographical areas.

${ }^{11}$ It should be noted that in each year information on sales lagged by one, two and three years is also available.

${ }^{12}$ According to the Portuguese Classification of Economic Activities (CAE), there are 448 sectors at the 5 digit level.
} 
is measured as the ratio of the total number of involuntary separations in the year (of permanent and temporary workers) by the firm's average employment in the year (in logs and lagged by one year).

When wages are largely set in the interest of the insiders workers, as predicted by the insider-outsider theory, it should be expected that layoff rates have a negative impact on wages, since higher layoff rates threaten the jobs of the insiders. Graafland (1992) using aggregate data for the Netherlands, showed that the layoff rate has a significant negative influence on wages.

In order to control for the aggregate outside labor market conditions, we decided to include a set of time dummies and the regional unemployment rate. The regional unemployment rate is defined at the level of NUTs II. ${ }^{13} \mathrm{~A}$ precise definition of all variables is presented in Appendix B.

The sample was limited to firms for which data are held for at least four consecutive years and with no missing values in the explanatory variables. To minimize the effects of outliers, we also excluded from the sample those firms whose real sales increase more than 5 times or decrease to less than one-fifth from one year to the next.

After these restrictions, we obtained an unbalanced panel of 820 firms and 5,150 observations. In Table 1 some selected variables are reported in order to characterize the sample over the 1993-99 period.

Table 1: Basic Characteristics of the Data (1993-99)

\begin{tabular}{|l|r|r|r|r|r|r|r|}
\hline \hline & 1993 & 1994 & 1995 & 1996 & 1997 & 1998 & 1999 \\
\hline Variables & & & & & & & \\
Employment & 261075 & 268385 & 274153 & 289411 & 287564 & 280908 & 269936 \\
Permanent employment & 218275 & 222836 & 227062 & 236781 & 231214 & 227484 & 216768 \\
Employment growth rate & 0.016 & 0.002 & -0.003 & 0.003 & 0.014 & -0.006 & -0.001 \\
Layoff rate & 0.029 & 0.024 & 0.027 & 0.029 & 0.028 & 0.029 & 0.027 \\
Labor utilization rate & 0.922 & 0.928 & 0.928 & 0.932 & 0.930 & 0.931 & 0.927 \\
Market share & 0.075 & 0.098 & 0.095 & 0.091 & 0.095 & 0.097 & 0.101 \\
Firm size & 378.9 & 371.2 & 361.2 & 352.9 & 367.7 & 391.2 & 409.6 \\
Sales per employee* & 59054.9 & 61269.7 & 62571.3 & 63045.7 & 69658.8 & 71804.4 & 74594.0 \\
Wages per employee* & 5947.5 & 5946.8 & 6062.0 & 6212.1 & 6495.8 & 6662.8 & 6700.3 \\
Outside wage per employee* & 4382.0 & 4585.2 & 4534.0 & 4660.4 & 4791.9 & 5004.4 & 4820.7 \\
& & & & & & & \\
Number of firms & 689 & 723 & 759 & 820 & 782 & 718 & 659 \\
\hline \hline
\end{tabular}

Note: * Annual real values (in Euros); CPI deflator (base $=1991$ ).

As can be seen in Table 1, the firms in the sample have an average size of 376 employees, $9.3 \%$ of market share, representing a total of about 276,000 workers. Permanent employment represents around $82 \%$ of total employment. Over the 1993-99 period, employment growth rates changed between a positive value of $1.6 \%$ in 1993 to a negative one of $0.1 \%$ in 1999 , representing involuntary

${ }^{13}$ At NUTs II mainland Portugal is split into 5 geographical areas. 
separations (layoffs) around $2.8 \%$ of average employment. On average, the labor utilization rate is around $93 \%$.

Between 1993 and 1999 real average wages in the firm grew, on average, at an annual rate of $2.0 \%$, whereas the outside wage in the region grew at an annual rate of $1.6 \%$. The average annual growth rate of real sales per employee was $4 \%$.

\subsection{Estimation Method}

The dynamic linear model of equation (1) is an autoregressive fixed effects model. In the presence of a model of such nature it is weel known that the ordinary least squares (OLS) estimator is inconsistent. A conventional way to tackle this problem is to use an instrumental variables estimation method. The application of the generalized method of moments (GMM) estimator suggested by Arellano and Bond (1991) overcomes these difficulties, producing consistent estimates. The GMM estimator identifies the parameters of the model under the assumption of lack of serial correlation in the error terms, and as this assumption is essential for the consistency of the estimator, a test of autocorrelation, developed in Arellano and Bond (1991), will be reported.

The empirical model will be estimated using the system (SYS) GMM estimator proposed by Arellano and Bover (1995) and Blundell and Bond (1998). The SYS GMM estimator uses lagged first differences as instruments for equations in levels in addition to the usual lagged levels as instruments for equations in first-differences. This option is justified by the fact that the SYS GMM estimator can dramatically improve the performance of the traditional first-differences (DIF) GMM estimator when the autoregressive parameter is moderately high and the number of time-series observations is moderately small. Indeed, the SYS GMM estimator has superior properties in terms of small sample bias and root mean squared error, especially for persistent series [see Blundell and Bond (1998)]. ${ }^{14}$

In fact, recent empirical studies have reported some problems with the estimation of dynamic panel data models using the DIF GMM estimator in cases of highly persistent regressors, which imply weak correlation of lagged levels with subsequent first differences. Mairesse and Hall (1996) and Blundell and Bond (1998), for example, showed that when the panel data are characterized by a large sample of firms observed over a small number of time periods, standard GMM estimators, which eliminate unobserved firm-specific effects firstdifferencing, have been found to produce unsatisfactory results. Blundell and Bond (2000) and Blundell et al. (2000) applied the SYS GMM estimator to panel production functions for the U.S. and also showed that the use of the SYS GMM estimator not only greatly improves the precision of the regression coefficient estimates but also greatly reduces the finite sample bias.

\footnotetext{
${ }^{14}$ The empirical model was first estimated using the DIF GMM estimator, but unreliable estimates were obtained for the wage equation coefficients.
} 


\section{Empirical Results}

\subsection{Measuring Insider Power}

The SYS GMM estimates of equation (1) for the unbalanced panel of 820 firms from all industries for the period 1994-99 are displayed in column (1) of Table $2 .{ }^{15}$ In order to control for the skill composition of the firm's workforce, each specification includes a set of controls for workers' skills. Thus, five levels of education (omitted category is basic school and less than basic school) and six levels of qualifications (omitted category is apprentices) were added to equation (1). ${ }^{16,17}$

\footnotetext{
${ }^{15}$ The equations are estimated using DPD98 (Dynamic Panel Data software) written by Arellano and Bond (1998).

${ }^{16}$ The Wald test of joint significance of the education and qualification levels rejects the hypothesis that the coefficients are all equal to zero. Moreover, the results revealed that controlling for workers' skills reduces the effect of nominal productivity on wages by around 5 percentage points, suggesting that there might exist a positive correlation between workers' skills and nominal productivity.

${ }^{17}$ These same estimates are reported in Appendix C for the manufacturing sector. Overall, the results are quite similar to the ones obtained for the full sample.
} 
Table 2: SYS GMM Estimates of Wage Equations (1994-99) Measuring Insider Power

Dependent variable: Wages $\left(w_{i t}-\bar{w}_{j t}\right)$

\begin{tabular}{|c|c|}
\hline & $(1)$ \\
\hline \multicolumn{2}{|l|}{ Independent Variables } \\
\hline Wages lagged $\left(w_{i t-1}-\bar{w}_{j t}\right)$ & $\begin{array}{r}0.232^{*} \\
(7.6)\end{array}$ \\
\hline Nominal productivity $\left(p_{i t}+y_{i t}-n_{i t}-\bar{w}_{j t}\right)$ & $\begin{array}{r}0.142^{*} \\
(6.1)\end{array}$ \\
\hline Growth permanent employment $\left(\Delta n_{\text {pit }}\right)$ & $\begin{array}{r}-0.098^{*} \\
(-5.9)\end{array}$ \\
\hline Market share $\left(M S_{i t-1}\right)$ & $\begin{array}{r}0.017^{*} \\
(4.3)\end{array}$ \\
\hline Regional unemployment rate $\left(u_{j t}\right)$ & $\begin{array}{r}-0.118^{*} \\
(-5.7)\end{array}$ \\
\hline Proportion of temporary employees $\left(\phi_{i t}\right)$ & $\begin{array}{r}-0.023 \\
(-0.7)\end{array}$ \\
\hline Labor utilization rate $\left(\operatorname{lur}_{i t-1}\right)$ & $\begin{array}{r}0.305^{* *} \\
(2.4)\end{array}$ \\
\hline Layoff rate $\left(\right.$ layof $\left.f_{i t-1}\right)$ & $\begin{array}{r}-0.022^{*} \\
(-5.2)\end{array}$ \\
\hline \multicolumn{2}{|l|}{ Education Levels } \\
\hline Preparatory and lower secondary & $\begin{array}{r}-0.010^{* * *} \\
(-1.6)\end{array}$ \\
\hline Upper secondary & $\begin{array}{r}0.009 \\
(1.5)\end{array}$ \\
\hline College & $\begin{array}{r}0.062^{*} \\
(7.6)\end{array}$ \\
\hline Others & $\begin{array}{r}0.000 \\
(0.0)\end{array}$ \\
\hline \multicolumn{2}{|l|}{ Qualification Levels } \\
\hline Manager and highly professional & $\begin{array}{r}0.006 \\
(0.7)\end{array}$ \\
\hline Professional & $\begin{array}{r}0.014^{* *} \\
(2.4)\end{array}$ \\
\hline Supervisors & $\begin{array}{r}0.012^{* *} \\
(2.2)\end{array}$ \\
\hline Highly skilled and skilled & $\begin{array}{r}0.021^{*} \\
(3.6)\end{array}$ \\
\hline Semi-skilled and unskilled & $\begin{array}{r}-0.002 \\
(-0.4)\end{array}$ \\
\hline Constant & $\begin{array}{r}-0.347^{*} \\
(-2.8)\end{array}$ \\
\hline Time dummies & yes* \\
\hline
\end{tabular}


Table 2: Continued

\begin{tabular}{|l|r|}
\hline \hline Wald (p-value) & $2144.0(.000)$ \\
Sargan (p-value) & $114.3(.066)$ \\
$\mathrm{m}_{1}$ (p-value) & $-4.5(.000)$ \\
$\mathrm{m}_{2}$ (p-value) & $1.7(.096)$ \\
$\mathrm{NT}$ & 4330 \\
\hline \hline
\end{tabular}

Notes: (i) Subscript i denotes firm, $\mathrm{j}$ refers to region and t denotes time;

(ii) t-statistics in parentheses;

(iii) $*, * *, * * *$ denote significant, at 1,5 and 10 percent, respectively;

(iv) The variables treated as endogenous are: $\left(w_{i t-1}-\bar{w}_{j t}\right), \Delta n_{p i t}$,

$\left(p_{i t}+y_{i t}-n_{i t}-\bar{w}_{j t}\right)$ and $\phi_{i t}$; instruments used are:

$w_{i t-2} \ldots w_{i t-6}, n_{p i t-2} \ldots n_{p i t-6},(p+y-n)_{i t-2} \ldots(p+y-n)_{i t-9}$,

$\phi_{i t-2} \ldots \phi_{i t-6}, \Delta w_{i t-1} \ldots \Delta w_{i t-5}, \Delta n_{p i t-1} \ldots \Delta n_{p i t-5}$,

$\Delta(p+y-n)_{i t-1} \ldots \Delta(p+y-n)_{i t-8}$, and $\Delta \phi_{i t-1} \ldots \Delta \phi_{i t-5}$.

The results of column 1 report a value of the insider weight $(\lambda)$ of $18 \%$, estimated with precision. ${ }^{18,19}$ This value is considerably higher than those obtained for other European Countries such as Spain and the U.K. using firm-level data (see Table A of Appendix A). In fact, the short-run effect of nominal productivity on wages is strong and significant (coefficient estimate of 0.142 ), suggesting that in Portugal wages are highly responsive to firm's performance. This is also consistent with one of the predictions of the insider-outsider theory that the greater the hiring and firing costs, the more the insider wage will depend on the "inside factors" relative to the "outside factors".

Other evidence is uncovered by the results. First, market share exerts a positive and significant impact on wages, suggesting that monopoly power generates monopoly rents that are captured by the employees in the form of higher wages.

Second, as expected, the regional unemployment rate has a negative and significant impact on wages. The elasticity of wages with respect to the regional unemployment rate is -0.118 , which is a value that is in accordance with previous estimates [see, for instance, Blanchflower et al. (1990) and Nickell et al. 1994]. This result reveals that outsiders' forces have an important role in wage determination in the sense that they affect the alternative options to the bargaining parties.

Third, there is no evidence of membership hysteresis effect when the insiders are measured by the number of permanent employees, contrary to the result obtained by Bentolila and Dolado (1994) for Spain. In fact, the coefficient on the permanent employment change $\left(\Delta n_{p}\right)$ is negative and statistically different

\footnotetext{
${ }^{18}$ The long-run value of the insider weight is calculated by dividing the nominal productivity coefficient (the short-run coefficient) by one minus the coefficient on the lagged wages.

${ }^{19}$ It should be noted that in the regression presented in Table 2, the test statistics reported verify the critical assumption of no second-order serial correlation ( $\mathrm{m}_{2}$ test) and the validity of the instruments (Sargan test) at the conventional levels of significance.
} 
from zero. ${ }^{20}$ This result is not too surprising since in Portugal, contrary to Spain, unemployment rates in the last decade remained at very low levels (5 to $6 \%$ ) with wages exhibiting a high aggregate wage flexibility. Thus, it is not expected that past employment has a significant impact on current wages.

Finally, we obtain the expected signs for the coefficients on the labor utilization rate and on the layoff rate. A $1 \%$ increase in lur raises wages, in the short run, by $0.31 \%$. Hence, workers in firms with higher labor utilization rates have higher insider power and, thus, earn more.

A $1 \%$ increase in the layoff rate decreases wages, in the short-run, by $0.022 \% .^{21}$ This finding seems to suggest that when the employment perspectives of employed workers worsen, they tend to restrain wage demands. ${ }^{22}$ Another interpretation is possible if the layoff rate is viewed as a proxy for labor adjustment costs. In firms with high (low) adjustment costs the risk of being fired is lower (higher) and thus insider workers are in a better position to extract rents in the form of higher wages.

In fact, besides the high dismissal costs that Portuguese employers have to bear, conditions in which a termination contract is admissible are also regulated quite strictly. These factors appear to work together to strenghten the bargaining position of incumbent workers and their power to claim for higher wages.

A small negative effect of the proportion of temporary employees on average wages was found, although not statistically different from zero. ${ }^{23}$

On balance, the results presented in this Section show that firms where insider workers have more market power tend to pay higher wages, ceteris paribus. In particular, in firms with low layoff rates and high rates of labor utilization within the firm, workers seem to extract rents in the form of higher wages.

\footnotetext{
${ }^{20}$ In this case, a coefficient of 0.131 (statistical significant at $10 \%$ ) was obtained for the change in total employment $(\Delta n)$.

${ }^{21}$ This result is reinforced by a composition effect of reverse sign that can emerge if we assume that temporary workers are the first ones to be fired because their lower firing costs.

${ }^{22}$ Blanchflower (1991) obtained a similar result using microeconomic data on individuals for the UK.

${ }^{23}$ In fact, we only obtained a negative and significant coefficient $(-0.069)$ for the temporary workers ratio when the layoff rate is excluded from the model. This happens, probably because the two variables are positively correlated.
} 


\subsection{Testing for Asymmetric Insider Effects}

Insider effects may be more important in expanding firms when compared to declining ones, and similarly, firms' wages may be more responsive to insider variables in good than in bad times. Such asymmetric insider effects imply downward wage rigidity, and will tend to put more pressure on employment when times are bad. Even though some empirical evidence was found that wage adjustments are asymmetric [see, for instance, Nickell and Wadhwani (1990), Blanchflower (1991), Holzer and Montgomery (1993) and Johansen (1996)], this issue remains unsettled and further evidence seems to be granted. In this Section we test the extent to which wages in Portugal are more responsive to insider variables in the face of rising demand than in the face of declining demand.

The major problem associated with the implementation of any test of asymmetry is that demand is not observed. In order to have a measure of expected demand we used the average rate of growth of real sales over the last three years as a proxy. ${ }^{24}$ Then we interact a dummy that takes the value one for positive rates of sales growth in the last three years (zero otherwise) with lagged wages and with nominal productivity. The regression estimates for the full sample are reported in column 1 of Table 3 .

As can be seen from Table 3, the interaction term between the sales growth dummy and nominal productivity is positive and statistically different from zero, suggesting that when sales are expected to grow the impact of productivity on wages is higher. The interaction term between the average growth rate of sales and lagged wages is also statistically significant and negative, suggesting that when demand is expected to rise the impact of last period's wage is reduced. Thus, the asymmetry test seems to reveal that wages in Portugal are less responsive to produtivity when demand is expected to decline and subject to greater inertia under these same circumstances. These results are quite similar to those obtained by Nickell and Wadhwani (1990).

\footnotetext{
${ }^{24}$ In order to avoid endogeneity problems and since in year $t$ we have information on sales in $t-1, t-2$ and $t-3$, we used the average rate of growth of real sales between $t-1$ and $t-3$.
} 
Table 3: SYS GMM Estimates of Wage Equations (1994-99)

Testing for Asymmetric Insider Effects

Dependent variable: Wages $\left(w_{i t}-\bar{w}_{j t}\right)$

\begin{tabular}{|c|c|}
\hline & $(1)$ \\
\hline Independent Variables & \\
\hline Wages lagged $\left(w_{i t-1}-\bar{w}_{j t}\right)$ & $\begin{array}{r}0.397^{*} \\
(7.8)\end{array}$ \\
\hline Nominal productivity $\left(p_{i t}+y_{i t}-n_{i t}-\bar{w}_{j t}\right)$ & $\begin{array}{r}0.138^{*} \\
\quad(5.6)\end{array}$ \\
\hline Employment growth $\left(\Delta n_{p i t}\right)$ & $\begin{array}{r}-0.096^{*} \\
(-5.9)\end{array}$ \\
\hline Market share $\left(M S_{i t-1}\right)$ & $\begin{array}{r}0.017^{*} \\
(4.0)\end{array}$ \\
\hline Regional unemployment rate $\left(u_{j t}\right)$ & $\begin{array}{r}-0.122^{*} \\
(-6.0)\end{array}$ \\
\hline Proportion of temporary employees $\left(\phi_{i t}\right)$ & $\begin{array}{r}-0.027 \\
(-0.8)\end{array}$ \\
\hline Labor utilization rate $\left(l u r_{i t-1}\right)$ & $\begin{array}{r}0.326^{*} \\
(2.7)\end{array}$ \\
\hline Layoff rate $\left(\right.$ layof $\left.f_{i t-1}\right)$ & $\begin{array}{r}-0.021^{*} \\
(-5.3)\end{array}$ \\
\hline Interaction Terms & \\
\hline Wages lagged*Sales growth dummy & $\begin{array}{r}-0.276^{*} \\
(-4.7)\end{array}$ \\
\hline Nominal productivity*Sales growth dummy & $\begin{array}{r}0.023^{*} \\
(3.9)\end{array}$ \\
\hline Constant & $\begin{array}{r}-0.406^{*} \\
(-3.3)\end{array}$ \\
\hline Time Dummies & yes* \\
\hline Wald (p-value) & $2164.8(.000)$ \\
\hline Sargan (p-value) & $102.4(.216)$ \\
\hline $\mathrm{m}_{1}(\mathrm{p}$-value $)$ & $-5.0(.000)$ \\
\hline $\mathrm{m}_{2}(\mathrm{p}$-value $)$ & $1.3(.186)$ \\
\hline NT & 4330 \\
\hline
\end{tabular}

Notes: see notes to Table 2; each regression includes five educational levels and six qualification levels.

Sales growth dummy $=1$ if sales growth $>0 ; 0$ otherwise. 


\section{Conclusion}

This study investigates wage determination at the firm level using a longitudinal panel of large firms in Portugal. The main empirical findings are the following.

First, insider forces such as revenue per employee and market share have a significant impact on wage determination. After controlling for the skill mix of the workforce, the full sample estimates imply a long-run insider weight of $18 \%$, which is comparable with estimates reported for economies characterized by a decentralized system of wage negotiation. The system of wage bargaining in Portugal exhibits characteristics of a centralized and regulated industrial regulation system, nevertheless the results of this study reveal that there is room for firm maneuvering. In fact, and even though collective bargaining imposes a binding constraint on the employer wage policy, wages seem to be very sensitive to firm-specific conditions, i. e, firm wages in Portugal are significantly affected by firm performance. This result is also consistent with one of the predictions of insider-outsider theory that the higher are the hiring and firing costs, the higher is the weight attached to insider forces.

Second, the idea that wages will be higher in sectors (firms) with high labor turnover costs and/or high job retention probabilities found empirical

support. Most notably, the results revealed that a threat of dismissal tends to weaken insiders' bargaining power and, consequently, to depress wages.

Third, outside labor market conditions measured by the regional unemployment rate also play an important role in wage determination. The regional unemployment level in the economy has an influence on the negotiated wage through the probabilities of finding a job. Thus, the negative and significant impact of the regional unemployment rate on wages suggests that workers are more inclined to accept wage moderation when the probabilities of finding a job worsen.

Finally, some evidence was found in favor of the existence of asymmetric insider effects. That is, real wages in Portugal seem to exhibit some downward rigidity. 


\section{References}

[1] Abowd, J. and T. Lemieux (1993), "The Effects of Product Market Competition on Collective Bargaining Agreements: The Case of Foreign Competition in Canada", Quarterly Journal of Economics, Vol. 108, pp. 983-1014.

[2] Arellano, M. and S. Bond (1991), "Some Tests of Specification for Panel Data: Monte Carlo Evidence and an Application to Employment Equations", Review of Economic Studies, Vol. 58, pp. 277-297.

[3] Arellano, M. and S. Bond (1998), "Dynamic Panel Data Estimation using DPD98 for Gauss: a Guide for Users", mimeo.

[4] Arellano, M. and O. Bover (1995), "Another Look at the Instrumental Variable Estimation of Error-components Models", Journal of Econometrics, Vol. 68, pp. 29-51.

[5] Bentolila, S. and J. Dolado (1994), "Labour Flexibility and Wages: Lessons from Spain", Economic Policy, Vol. 18, pp. 55-99.

[6] Blanchard, O. and P. Portugal (2001), "What Hides Behind an Unemployment Rate: Comparing Portuguese and U.S. Labor Markets", American Economic Review, Vol. 91, pp. 187-207.

[7] Blanchard, O. and L. Summers (1986), "Hysteresis and the European Problem", NBER Macroeconomics Annual, Cambridge, MIT Press.

[8] Blanchflower, D. (1991), "Fear, Unemployment and Pay Flexibility", Economic Journal, Vol. 101, pp. 483-496.

[9] Blanchflower, D., A. Oswald and M. Garrett (1990), "Insider Power in Wage Determination", Economica, Vol. 57, pp. 143-170.

[10] Blanchflower, D., A. Oswald and P. Sanfey (1996), "Wages, Profits and Rent-Sharing", Quarterly Journal of Economics, Vol. 111, pp. 227-251.

[11] Blundell, R. and S. Bond (1998), "Initial Conditions and Moment Restrictions in Dynamic Panel Data Models", Journal of Econometrics, Vol. 87, pp. 115-143.

[12] Blundell, R. and S. Bond (2000), "GMM Estimation with Persistent Panel Data: an Application to Production Functions", Econometric Review, Vol. 19, pp. 321-340.

[13] Blundell, R., S. Bond and F. Windmeijer (2000), "Estimation in Dynamic Panel Data Models: Improving on the Performance of the Standard GMM Estimators", Institute for Fiscal Studies Working Paper WP 00/12.

[14] Cardoso, A. and P. Portugal (2005), "Contractual Wages and the Wage Cushion under Different Bargaining Settings," Journal of Labor Economics, forthcoming. 
[15] Forslund, A. (1994), "Wage Setting at the Firm Level - Insider versus Outsider Forces", Oxford Economic Papers, Vol. 46, pp. 245-261.

[16] Gregory, R. (1986), "Wages Policy and Unemployment in Australia", Economica, Vol. 53, pp. S53-S74.

[17] Gottfries, N. and H. Horn (1987), "Wage Formation and Unemployment Persistence", Economic Journal, Vol. 97, pp. 877-886.

[18] Graafland, J. (1992), "Insiders and Outsiders in Wage Formation: The Dutch Case", Empirical Economics, Vol. 17, pp. 583-602.

[19] Hildreth, A. and A. Oswald (1997), "Rent-Sharing and Wages: Evidence from Company and Establishment Panels", Journal of Labor Economics, Vol. 15, pp. 318-337.

[20] Holmlund, B. and J. Zetterberg (1991), "Insider Effects in Wage Determination - Evidence from Five Countries", European Economic Review, Vol. 35, pp. 1009-1034.

[21] Holzer, H. and E. Montgomery (1993), "Asymmetries and Rigidities in Wage Adjustments by Firms", Review of Economics and Statistics, Vol. 75, pp. 397-408.

[22] Johansen (1996), K., "Insider Forces, Asymmetries, and Outsider Inefectiveness: Empirical Evidence for Norwegian Industries 1966-87", Oxford Economic Papers, Vol. 48, pp. 89-104.

[23] Layard, R., S. Nickell and R. Jackman (1991), Unemployment: Macroeconomic Performance and the Labour Market, Oxford: Oxford University Press.

[24] Lever, M. and J. van Werkhooven (1996), "Insider Power, Market Power, Firm Size and Wages: Evidence from Dutch Manufacturing Industries", Labour Economics, Vol. 3, pp. 93-107.

[25] Lindbeck, A. and D. Snower (1985), "Explanations of Unemployment", Oxford Review of Economic Policy, Vol. 2, pp. 34-69.

[26] Lindbeck, A. and D. Snower (1986), "Wage Setting, Unemployment, and Insider-Outsider Relations", American Economic Review Proceedings, Vol. 76, pp. 235-239.

[27] Lindbeck, A. and D. Snower (1988), "Cooperation, Harassment, and Involuntary Unemployment: an Insider-Outsider Approach", American Economic Review, Vol. 78, pp. 167-188.

[28] Lindbeck, A. and D. Snower (2002), "The Insider-Outsider Theory: a Survey", IZA Discussion Paper $N^{o} 534$. 
[29] Mairesse, J. and B. Hall (1996), "Estimating the Productivity of Research and Development in French and US Manufacturing Firms: an Exploration of Simultaneity Issues with GMM Methods", in K. Wagner and B. van Ark eds., International Productivity Differences and Their Explanations, Elsevier Science, pp. 283-315.

[30] Nickell, S. and P. Kong (1992), "An investigation into the Power of Insiders in Wage Determination", European Economic Review, Vol. 36, pp. 15731599.

[31] Nickell, S., J. Vainiomaki and S. Wadhwani (1994), "Wages and Product Market Power", Economica, Vol. 61, pp. 457-473.

[32] Nickell, S. and S. Wadhwani (1990), "Insider Forces and Wage Determination", Economic Journal, Vol. 100, pp. 496-509.

[33] Organization for Economic Cooperation and Development (1999), OECD Employment Outlook, Paris: OECD.

[34] Solow (1985), R., "Insiders and Outsiders in Wage Determination", Scandinavian Journal of Economics, Vol. 87, pp. 411-428.

[35] Teulings, C. and J. Hartog (1998), Corporatism or Competition? Labour Contracts, Institutions and Wage Structures in International Comparison, Cambridge: Cambridge University Press.

[36] Wulfsberg, F. (1997), "An Application of Wage Bargaining Models to Norwegian Panel Data", Oxford Economic Papers, Vol. 49, pp. 419-440. 


\section{APPENDIX A - Previous Research}

Table A: Estimates of $\lambda$, the long-run elasticity of firm (industry) wages with respect to firm (industry) revenue per employee

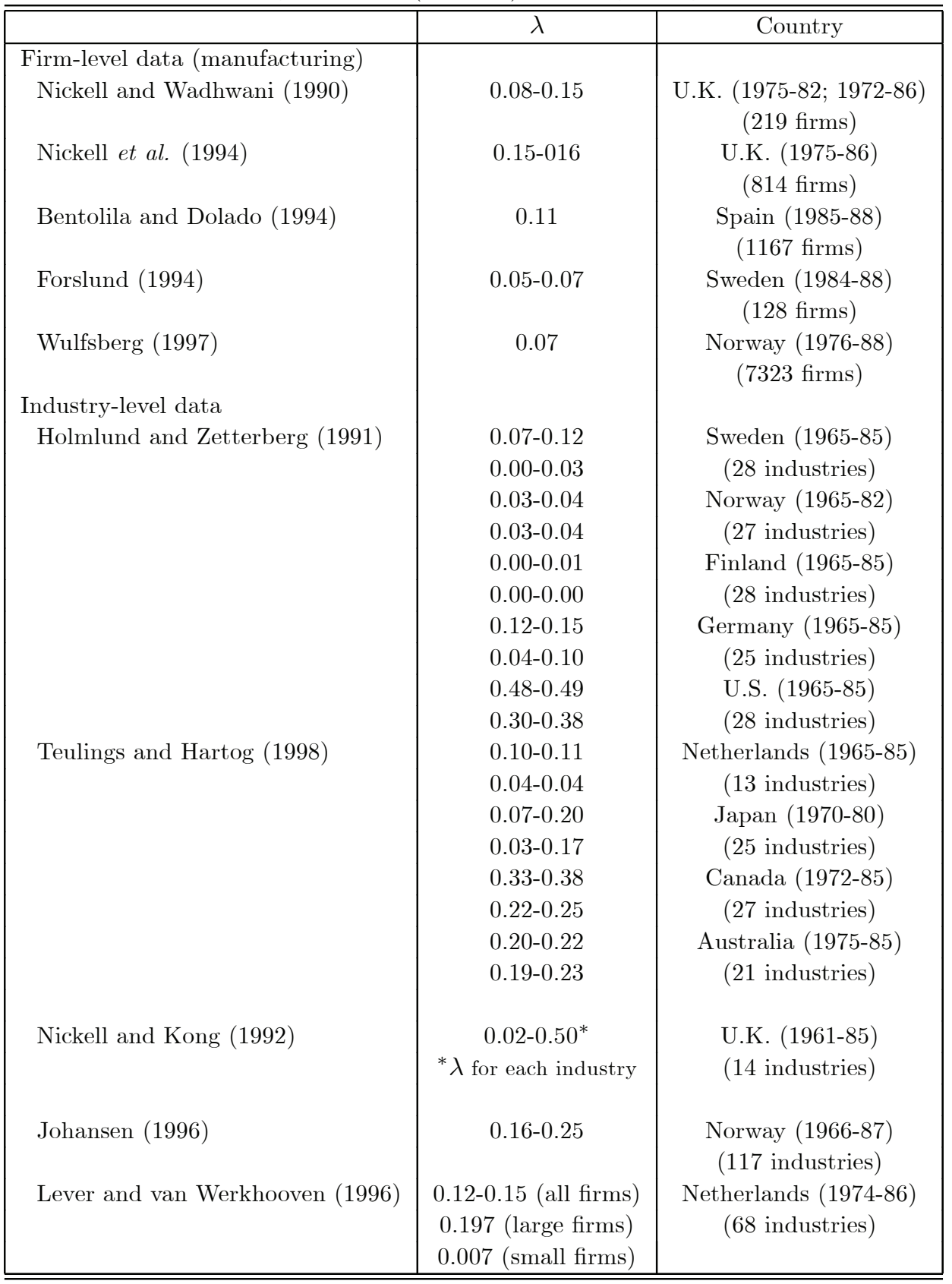

Note: In Holmlund and Zetterberg (1991) and Teulings and Hartog (1998), for each country, the first range for $\lambda$ refers to trend productivity and the second to industry relative price. 


\section{APPENDIX B - Variables: Definition ${ }^{25}$ and Source ${ }^{26}$}

Average employment: defined as the mean between the number of workers at the beginning of the year and the number of workers at the end of the year; Social Audit;

Wages: annual real labor cost (base wage + regular paid benefits and premiums) divided by average employment; Social Audit;

Nominal productivity: annual sales at constant prices divided by average employment; Quadros de Pessoal and Social Audit;

Market share: total sales in each firm divided by total sales in the sector defined at 5 digits according to CAE; Quadros de Pessoal;

Employment growth: measured as the annual rate change in the total number of permanent employees; Social Audit;

Proportion of temporary employees: the number of temporary employees in the end-of-year count as a proportion of total employment in the end-of-year count; Social Audit;

Labor utilization rate: the ratio between the number of total hours actually worked and the maximum annual potential of worked hours; Social Audit;

Layoff rate: total number of workers (permanent and temporary) who left involuntarily the firm over the year divided by average employment; Social Audit;

Outside wage: aggregate real wage by region (defined at NUTs III) excluding the firm's own wage (per employee); Quadros de Pessoal;

Regional unemployment rate: defined at the level of NUTs II; Employment Survey - INE (Instituto Nacional de Estatística);

Education: five educational levels were defined (proportion of workers) primary and less than primary (the omitted category), preparatory and lower secondary, upper secondary, college and others (a residual category); Social Audit;

Qualification: six qualification levels were defined (proportion of workers) - manager and highly professional, professional, supervisors, skilled and highly skilled, semiskilled and unskilled and apprentices (the omitted category); Social Audit;

Price deflator: Consumer Price Index (1991=100); Consumer Price Index INE.

\footnotetext{
${ }^{25}$ All variables, except the proportion of temporary workers, are in logs.

${ }^{26}$ Data sources are in italics.
} 


\section{APPENDIX C - SYS GMM Estimates: Manufacturing Firms}

Table C: SYS GMM Estimates of Wage Equation (1994-99)

Manufacturing Firms

Measuring Insider Power

Dependent variable: Wages $\left(w_{i t}-\bar{w}_{j t}\right)$

\begin{tabular}{|l|r|}
\hline \hline & $(1)$ \\
\hline Independent Variables & $0.266^{*}$ \\
Wages lagged $\left(w_{i t-1}-\bar{w}_{j t}\right)$ & $(9.3)$ \\
Nominal productivity $\left(p_{i t}+y_{i t}-n_{i t}-\bar{w}_{j t}\right)$ & $0.180^{*}$ \\
& $(8.1)$ \\
Growth permanent employment $\left(\Delta n_{p i t}\right)$ & $-0.024^{*}$ \\
& $(-3.4)$ \\
Market share $\left(M S_{i t-1}\right)$ & $0.011^{* *}$ \\
& $(2.1)$ \\
Regional unemployment rate $\left(u_{j t}\right)$ & $-0.096^{*}$ \\
Proportion of temporary employees $\left(\phi_{i t}\right)$ & $(-5.5)$ \\
Labor utilization rate $\left(l u r_{i t-1}\right)$ & -0.024 \\
Layoff rate $\left(\right.$ layof $\left.f_{i t-1}\right)$ & $(-0.6)$ \\
Constant & $0.496^{*}$ \\
Time dummies & $(3.8)$ \\
Wald (p-value) & $-0.019^{*}$ \\
Sargan (p-value) & $(-5.2)$ \\
$\mathrm{m}_{1}$ (p-value) & $-0.536^{*}$ \\
$\mathrm{~m}_{2}$ (p-value) & $(-4.8)$ \\
NT & yes* \\
\hline \hline Notes: & $1886.0(.000)$ \\
\end{tabular}

Notes: see notes to Table 2; each regression includes five educational levels and six qualification levels. 